\title{
THE EFFECT OF HUMANISTIC APPROACH ON STUDENTS' LEARNING MOTIVATION OF CLASS XI OF SMA NEGERI 3 TARUTUNG DURING COVID-19 PANDEMIC
}

\author{
Oktober Tua Aritonang \\ Institut Agama Kristen Negeri (IAKN) Tarutung \\ Jalan Raya Tarutung - Siborongborong KM. 11 Silangkitang, Sipoholon, Sumatera Utara \\ Email: otaritonang68@gmail.com
}

\begin{abstract}
:
The purpose of study is to determine whether there is a positive and significant effect of humanistic approach on learning motivation of class XI students of SMA Negeri 3 Tarutung during Covid-19 pandemic. This research is quantitative descriptive by using descriptive statistic method. The population is 143 students of class XI and the sample of $25 \%$, namely 36 students were taken randomly. A closed questionnaire was used as the instrument for the data collection. The data processing and analysis techniques used simple linear regression method with $t$-test. The regression equation was $\mathrm{Y}=2.5+0.21 \mathrm{X}+\mathrm{e}$. The value of $\mathrm{X}$ was positive value, it indicated that the better humanistic approach is applied, the more student motivation will be. Based on the data analysis, it was known that the significance value of the humanistic approach variable was 0.047 . The results show that the significance value $(0.047)$ is smaller than the value of $0.050(\alpha)$. Therefore, it is concluded that $\mathrm{H} 0$ is rejected and Ha is accepted. It means that the humanistic approach has a positive and significant effect on students' learning motivation.
\end{abstract}

\begin{abstract}
Abstrak:
Tujuan penelitian ini untuk mengetahui ada tidaknya pengaruh yang positif dan signifikan pendekatan humanistik oleh guru terhadap motivasi belajar siswa kelas XI SMA Negeri 3 Tarutung pada masa pandemi Covid-19. Penelitian ini deskriptif kuantitatif dengan menggunakan metode statistik deskriptif. Populasi 143 siswa kelas XI dan sampel $25 \%$ yaitu 36 orang diambil secara random.Teknik pengumpulan data dengan angket tertutup. Teknik pengolahan dan analisis data menggunakan metode regresi linier sederhana dengan uji-t. Persamaan regresi yaitu $Y=2,5+0,21 \mathrm{X}+$ e. Nilai $\mathrm{X}$ adalah nilai positif, ini menunjukkan bahwa semakin baik pendekatan humanistik dilakukanguru akan mengakibatkan motivasi belajar siswa semakin meningkat.Dari hasil analisis diketahui bahwa nilai signifikansi variabel pendekatan humanistik oleh guru adalah sebesar 0,047. Karena nilai signifikansi 0,047 lebih kecil daripada nilai 0,050 $(\alpha)$ maka disimpulkan bahwa H0 ditolak dan Ha diterima. Ini berarti bahwa pendekatan humanistik oleh guru mempunyai pengaruh yang positif dan signifikan terhadap motivasi belajar siswa.
\end{abstract}

\section{Keywords:}

Humanistic Approach, Learning Motivation

How to Cite: Aritonang, O. T. (2021). The Effect of Humanistic Approach on Students' Learning Motivation of Class XI of SMA Negeri 3 Tarutung During COVID-19 Pandemic. Lentera Pendidikan : Jurnal Ilmu Tarbiyah dan Keguruan, 24(2), 224-237. https://doi.org/10.24252/lp.2021v24n2i6. 


\section{INTRODUCTION}

Since the outbreak of the Corona Virus Disease (Covid-19) in Indonesia in March 2020 , it has had a wide-ranging impact on all aspects of human life, including education, particularly the learning process in schools. The face-to-face learning system in the classroom has shifted to distance learning aided by the internet network, also known as online learning. This change is expected to be successful and efficient, however, the internet or online learning process is not conducive. Students get depressed and even stressed as a result of the teacher's workload. Meanwhile, many students continue to struggle with the content presented by the teacher, owing to the subject teacher's in-depth discussion (Hasan, 2020). In addition, students also experience the "violence" with the systematic teaching load which is so heavy (Haryanto \& Dwiningrum, 2020).

The issue that has been raised is also faced by the teachers at SMA Negeri 3 Tarutung, namely a decline in student learning motivation of all subjects, as evidenced by several indicators such as students do not respond when the teacher asks questions, they are late in collecting their assignments, and some do not collect them at all, they leave the meeting after filling in the attendance list, they are too lazy to read the textbook, and they complain of being fatigued because they are bored and under pressure from the teacher's enormous number of tasks. To address this issue, the teacher needs to develop a learning environment that is favorable to accomplishing effective and efficient learning goals. The teacher's initial step in the learning process is to engage students to participate actively in the process, and the students are encouraged and motivated to learn continually wherever and whenever they can (Suyanto \& Asep, 2013).

Since the beginning of the even semester for academic year of $2020 / 2021$, the teachers at SMA Negeri 3 Tarutung have begun to apply the methods of humanistic approach, namely creating open communication and showing empathy for students, to a learning method that previously only focused on delivering material (Rahmi, 2021). The teacher inquires about the student's health and any complaints they may have and tries to offer good counsel while demonstrating empathy for their feelings. The objective is for the students to be willing to listen to the instruction so that they have inner awareness and they are motivated to learn. The teachers act as facilitators to assist students in their learning processes. Therefore, humanistic approach should be applied in the process of learning and teaching in order to produce a good learner and a critical of reality (Firdaus \& Mariyat, 2017). There are some studies that are addressed to humanistic approach. Haryanto \& Dwiningrum (2020) state that the implementation of humanistic theory has become an essential requirement in education system due to the mobility of technology. They found three powers in humanistic approach such as power to, power with, and power within, to enhance students' ability to overcome the challenges of the Industrial Revolution 4.0. In addition, Firdaus \& Mariyat (2017) emphasize that the implication of humanistic approach in education is how teachers encourage students to think critically and act according to the values of humanity. In this study, the researcher intends to explore the implementation of humanistic approach in order to get the latest information regarding to the effectiveness of humanistic approach on students' learning motivation. The researcher 
believes that humanistic approach is one solution that could be applied in Covid-19 pandemic to motivate students to learn.

Furthermore, humanistic learning model is an effective way to develop students' motivation especially in writing subjects. The students' motivation are shown in four aspects of motivation, namely students' attention, relevance, confidence, and satisfaction. Humanism emphasizes the importance of the individual and the main assumptions underlie on seven principles of humanism, namely: (1) human nature is inherently good, (2) individuals are free and autonomous so they can make their choices, (3) humans have unlimited potential for development, (4) self-concept has an important role in growth and development, (5) individuals are encouraged to move towards self-actualization, (6) each person defines reality by himself, and (7) individuals have responsibility for themselves and for others (Farikah, 2019).

Moreover, humanistic approach will be successful by applying four components, such as: (1) positive learning environments: leads to better outcomes by creating environments that are open, tolerant, non-competitive, enjoyable and safe, (2) selfmotivated students: students learn positive self-concepts, have a better understanding of their abilities, gain experience in making choices, and build self-esteem and a sense of intrinsic motivation, (3) teacher as facilitator: the teachers are seen as partners in learning and help students develop communication and social skills, and boost their self-esteem, and (4) self-evaluation: evaluation is based on their own growth and abilities and helps further stimulate their motivation. Thus, it makes them self-reflect and learn to be selfguided (PourAli, SeifNaraghi, \& Naderi, 2017).

To explore how the application of the humanistic approach and its implications for students' learning motivation, the components or principles of the humanistic approach and learning motivation in this study are further expanded. There are ten principles of the humanistic approach, namely: (1) learning activities foster a passion or desire to learn, (2) meaningful learning, (3) learning without threats, (4) learning on their own initiative, (5) learning for change, (6) showing an attitude of understanding, (7) creating openness, (8) having empathy, (9) fostering supportive behavior, and (10) fostering positive behavior. On the other hand, learning motivation includes eight components, namely: (1) persevering in facing tasks, (2) being tenacious in facing difficulties, (3) showing interest, (4) preferring to work independently, (5) getting bored quickly on routine tasks, (6) being able to defend opinions, (7) not being easy to let go of things that are believed and, (8) being happy to find and solve problems.

The concept of learning according to the humanistic approach is more directed at the development of the individual's personality so that it focuses on one's potential to seek and find the abilities that exist in him and develop these abilities (Supatminingsih, Hasan, \& Sudirman, 2020). The humanistic approach seeks to shape students to have commitments such as responsibility, awareness, freedom and understanding themselves living in a society so that a moral responsibility appears to devote themselves to the benefit of others (Munifah \& Dodi, 2020). 
The learning process with a humanistic approach applies several principles that must be done by the teacher, namely: learning activities must be able to foster students' passion or desire in learning, meaningful learning, learning without threats, learning on their initiative, and learning for change (Suzana, Jayanto, \& Farm, 2021). The first and main step that the teachers must take in learning activities with a humanistic approach is to build or establish interpersonal communication between individuals, namely between teachers and students, between fellow and students, and between groups in the learning community. To realize this relationship, the communication established by the teacher must be based on love between one another. Individuals in the learning community only develop optimally if a learning atmosphere is created that is full of love and a heart that is full of understanding (understanding heart) and effective interpersonal relationships (personal relationships) (Arbayah, 2013).

The interpersonal relationships that the teacher creates in the learning process in the form of communication must be symmetrical and complimentary, meaning that even if there are many distinct behaviors in communication, they must complement one another to avoid conflict. It is necessary to pay attention to several aspects to create deep interpersonal communication in learning activities, including openness, empathy, supportive behavior, positive behavior, and aspects of equality, which means accepting other parties or giving unconditional positive rewards to other parties (Rahmi, 2021). A good intrapersonal and interpersonal intelligences might raise the spirit of high achievement and not give up easily. They work hard without coercion from the teacher or not because they are being chased by the given time limit. The Intrapersonal and interpersonal intelligence can grow in students by applying humanistic learning (Gasong \& Toding, 2020).

Motivation is a fundamental component in learning activities because someone who lacks the desire to learn would not participate in learning activities. Individual students learn to direct their behavior such that they are encouraged to carry out learning activities to attain certain goals, and this is known as motivation to learn. Motivation serves as a motivator for a person to carry out an activity or a driving force to define the course of action for the attainment of objectives and select actions, which entail deciding what to do and avoid to accomplish objectives in each individual. Furthermore, motivation encourages students to work hard to reach their learning goals. A student who is motivated to study is eager and dedicated to his or her studies. The student's motivation to learn can be seen in a variety of attitudes and behaviors, including being diligent in completing tasks, being resilient in the face of difficulties, demonstrating interest, preferring to work independently, becoming bored quickly with routine tasks, being able to defend opinions, not easily letting go of things that are believed, and being eager to find and solve questions (Sardiman, 2011).

As a result, the teacher's involvement in developing an active and effective learning process is required for learning activities to succeed in accomplishing the goal. The teachers must strive to maintain their students' learning motivation so that they are eager to engage in learning activities on their initiative rather than under pressure or the threat 
of punishment (Rahmat, 2018). In other words, the teachers need to apply a humanistic approach in the teaching-learning process. The education systems that apply a humanistic approach should encourage an environment in which the students are self-motivated, control their learning, and learn to self-evaluate. There are four essential components of education that are applied in humanistic approach, namely: (1) a positive learning environment that is safe, reflective, tolerant, non-judgmental; (2) the students are selfmotivated, responsible for their education and motivated from within not by reward or punishment; (3) the teacher as a facilitator must create a positive learning environment, provide resources for students who acquire interests or talents in a particular field, develop emotional stability and self-esteem, and tolerate and understand the differences in learning styles and abilities, and (4) self-evaluation means having a deeper understanding of self that is obtained through self-evaluation and teaching students to develop independently (PourAli, SeifNaraghi, \& Naderi, 2017).

The implementation of a humanistic approach in learning activities can foster enthusiasm and motivation for students' learning because the humanistic approach lays the foundation on several principles, namely: learning activities must be able to foster passion or desire of students in learning, meaningful learning, learning without threats, learning on their initiative, and learning for change. The learning process begins with the teacher and students developing pleasant and enjoyable interpersonal interactions. The teachers treat the students with respect, inquire about their challenges or obstacles, and avoid being autocratic or issuing threats of punishment.

In addition, the humanistic approach is an effective method for increasing student enthusiasm and participation in classroom activities. Through open interpersonal communication and a personal approach, the teacher considers the students as personals who require personalized attention, guidance, and motivation. The students will be successful in their learning activities if they have the awareness to learn from their initiative, comprehend their existence and potential, and can develop their potential.

Based on the issues raised, it is explained that beginning with the start of the even semester for academic year of 2020/2021, the teachers at SMA Negeri 3 Tarutung began to change their learning methods, which had previously from only focusing on delivering material to beginning to apply a humanistic approach in the hopes of increasing students' learning motivation. Therefore, the purpose of this study is to determine whether there is a positive and significant effect of the humanistic approach applied by the teachers to the learning motivation of class XI students of SMA Negeri 3 Tarutung during the Covid-19 pandemic.

\section{RESEARCH METHOD}

This research is quantitative descriptive by using descriptive statistic method. The students from class XI PMIA and class XI PIIS SMA Negeri 3 Tarutung were selected as the data sources for this study. The respondents were given questionnaires to fill out as a part of the data collection process. The questionnaire instrument utilized was a closed questionnaire with details of 20 questions produced from 10 indicators for $\mathrm{X}$ variable 
(humanistic approach) and 16 items derived from 8 indicators for Y variable (students' motivation). All students in class XI PMIA and class XI PIIS SMA Negeri 3 Tarutung were included in the study, which consisted of two classes with a total number of 143 students. The research sample was $25 \%$ of the total population, namely 36 people, with a random sampling technique (random). The questionnaire has been tried out on 30 students of class $\mathrm{XI}$ outside the sample. From the results of the validity test, it is known that the $\mathrm{r}$ value of each item of $X$ variable is between 0.367 to 0.744 . Each item of the $X$ variable was valid because of the value of $r$-count $>r$-table (0.361). In the reliability test of $X$ variable, it was known that the Cronbach Alpha value is 0.870 which is strong category. The results of the validity and reliability test of $Y$ variable showed that all items were valid and reliable where $r$ value $(0.373-0.785)>r$ table $(0.361)$ and the Cronbach Alpha value 0.846 were in the strong category. The data analysis used linear regression where the t-test was used to see the significance influence of the humanistic approach on the students' learning motivation by using SPSS version 23 .

\section{RESULTS AND DISCUSSION}

The result of the data analysis on the instrument can be seen on the following table.

Table 1. Frequency of humanistic approach

\begin{tabular}{|c|c|c|}
\hline Indicator & $\begin{array}{c}\text { Frequency } \\
\text { (n) }\end{array}$ & $\begin{array}{c}\text { Persentage } \\
(\%)\end{array}$ \\
\hline \multicolumn{3}{|c|}{ 1. Learning activities to foster desire to learn } \\
\hline Never & 0 & 0.0 \\
\hline Sometimes & 4 & 11.1 \\
\hline Often & 13 & 36.1 \\
\hline Always & 19 & 52.8 \\
\hline \multicolumn{3}{|l|}{ 2. Meaningful learning } \\
\hline Never & 1 & 2.8 \\
\hline Sometimes & 6 & 16.7 \\
\hline Often & 17 & 47.2 \\
\hline Always & 12 & 33.3 \\
\hline \multicolumn{3}{|l|}{ 3. Learning without threats } \\
\hline Never & 1 & 2.8 \\
\hline Sometimes & 1 & 2.8 \\
\hline Often & 15 & 41.7 \\
\hline Always & 19 & 52.8 \\
\hline \multicolumn{3}{|l|}{ 4. Learning on your initiative } \\
\hline Never & 0 & 0.0 \\
\hline Sometimes & 2 & 5.6 \\
\hline Often & 15 & 41.7 \\
\hline Always & 19 & 52.8 \\
\hline \multicolumn{3}{|l|}{ 5. Learning for change } \\
\hline Never & 0 & 0.0 \\
\hline Sometimes & 4 & 11.1 \\
\hline
\end{tabular}




\begin{tabular}{|c|c|c|}
\hline Often & 16 & 44.4 \\
\hline Always & 16 & 44.4 \\
\hline \multicolumn{3}{|c|}{ 6. Showing understanding } \\
\hline Never & 1 & 2.8 \\
\hline Sometimes & 4 & 11.1 \\
\hline Often & 16 & 44.4 \\
\hline Always & 15 & 41.7 \\
\hline \multicolumn{3}{|c|}{ 7. Creating openness } \\
\hline Never & 0 & 0.0 \\
\hline Sometimes & 2 & 5.6 \\
\hline Often & 17 & 47.2 \\
\hline Always & 17 & 47.2 \\
\hline \multicolumn{3}{|c|}{ 8. Having empathy } \\
\hline Never & 1 & 2.8 \\
\hline Sometimes & 6 & 16.7 \\
\hline Often & 17 & 47.2 \\
\hline Always & 12 & 33.3 \\
\hline \multicolumn{3}{|c|}{ 9. Cultivating supportive behavior } \\
\hline Never & 0 & 0.0 \\
\hline Sometimes & 0 & 0.0 \\
\hline Often & 11 & 30.6 \\
\hline Always & 25 & 69.4 \\
\hline \multicolumn{3}{|c|}{ 10. Cultivating positive behavior } \\
\hline Never & 1 & 2.8 \\
\hline Sometimes & 4 & 11.1 \\
\hline Often & 14 & 38.9 \\
\hline Always & 17 & 47.2 \\
\hline
\end{tabular}

The variable of humanistic approach consists of ten indicators where each indicator consists of two instruments. In Table 1, it is known that the respondents thought that the teacher had implemented a humanistic approach in the process of daily teaching and learning activities. In the indicator of learning activities to foster students' passion or desire to learn, 19 respondents (52.8\%) stated that the teachers always did it. Meanwhile, 13 respondents (36.1\%) stated that the teachers often did it, 4 respondents (11.1\%) stated that the teachers sometimes did it, and there are no respondents who stated that the teachers never did it. It shows that the teachers have made maximum efforts to create learning activities that can foster students' desire to learn.

In the indicator of learning without threats, in general, the respondents stated that the teachers tried to create an atmosphere of learning without threats. It is known that 19 respondents (52.8\%) stated that the teachers always did it, 15 respondents (41.7\%) stated that teachers often did it, 1 respondent (2.8\%) stated that teachers sometimes did it, and 
1 person $(2.8 \%)$ stated the teachers never did. The data show that although there are respondents $(2.8 \%)$ stated that the teachers sometimes and never, but actually the teachers have tried to avoid the students' learning process by threatening the students to learn.

Based on the indicator of learning their initiative, it is known that 19 respondents (52.8\%) stated that the teachers always motivated students to learn on their initiative, 15 respondents (41.7\%) stated that the teachers often did it, 2 respondents (5.6\%) stated the teachers sometimes did it, and none of the respondents stated that the teachers never did. Therefore, the data show that the teachers have tried to guide students to learn on their initiative.

The indicator of learning for change shows that 16 respondents (44.4\%) stated that the teachers always did learning for change, 16 respondents $(44.4 \%)$ stated that the teachers often did learning for change, 4 respondents $(11.1 \%)$ stated that the teachers sometimes did learning for change, and none of respondents stated that the teachers never did it. Based on the data, it shows that in the learning process, the teachers have made efforts so that the learning process that they managed can have an impact on students to achieve changes both in terms of habits and in their abilities which include cognitive, affective and psychomotor.

Furthermore, the indicator of understanding attitude shows that as many as 15 respondents $(41.7 \%)$ stated that the teachers always did, 16 respondents $(44.4 \%)$ said that the teachers often did, 4 respondents $(11.1 \%)$ stated that the teachers sometimes did, and 1 respondent (2.8\%) stated that the teachers never did. The data show that in general the teachers have shown an understanding attitude in the process of learning activities, which means that the teachers understand all the weaknesses and strengths of their students so that they do not blame the students who do not understand the subject matter or those who are less responsive to the learning process but provide encouragement or guidance.

In the indicator of creating openness, it is known that 17 respondents (47.2\%) stated that the teachers did it, 17 respondents (47.2\%) stated that the teachers often did it, 2 respondents $(5.5 \%)$ said that the teachers sometimes did it, and there were no respondents who stated that the teachers never did. Therefore, the data show that the majority of teachers have tried to create openness by establishing communication or closeness with students so that the students who are involved in the learning activities want to honestly and openly state what and how teachers should do so that they are encouraged to actively carry out the learning activities.

The indicator of fostering supportive behavior shows that the respondents rated the teachers as having done it well. Based on the respondents' opinions, it is known that 25 respondents (69.4\%) stated that the teachers always did it, 11 respondents (30.6\%) stated that the teachers often did it and there were no respondents who stated that the teachers sometimes or never did it. So, it is clear that the data show that the teachers have made maximum efforts to foster supportive behavior, namely willing to accept other people's opinions or to respect the students' opinions so that the students feel valued and supported so that they will be enthusiastic for learning. 
In the next indicator, namely fostering positive behavior, it is known that 17 respondents (47.2\%) stated that the teachers always did it, 14 respondents (38.9\%) said that the teachers often did it, 4 respondents $(11.1 \%)$ stated that the teachers sometimes did it, and 1 respondent (2.8\%) stated that the teachers had never done it. The data also indicate that the indicator of fostering positive behavior in learning activities has been carried out by the majority of teachers, although some respondents stated that the teachers only occasionally or even never did that. In the process of learning activities, the attitude that the teachers must show is not to think negatively about the students' learning behavior, so that the students will not feel pressured or blamed when they do not respond in the learning process, but the teachers find out the cause to find a solution (Stefaroi, 2012).

Based on the data description in Table 1, there are two indicators that the teachers should pay attention, namely learning should be meaningful and have a sense of empathy. The results of the data analysis show that the frequency of the number of respondents thinks that the teachers sometimes did it quite high, reaching 16.7\% (6 respondents) if compared to the other indicators that can be seen in the following figure.

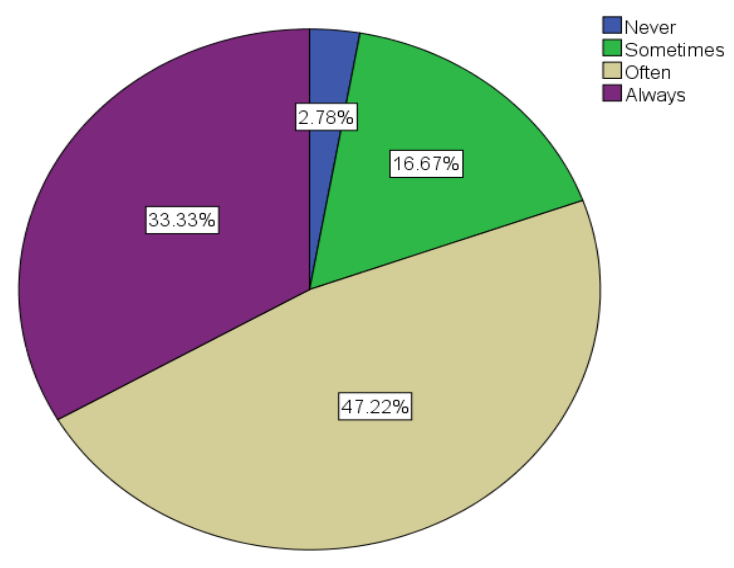

Figure 1. Indicator frequency of Meaningful Learning

Figure 1 shows that $33.33 \%$ (12 respondents) stated that the teachers always do meaningful learning and have a sense of empathy, $47.22 \%$ (17 respondents) stated often, $16.67 \%$ (6 respondents) stated sometimes, and $2.78 \%$ (1 respondent) stated that the teachers never do meaningful learning and have a sense of empathy in learning activities. The data from respondents' responses for indicator of empathy have exactly the same frequency as meaningful learning indicator. It means that these two indicators need teachers' attention when managing learning activities. The data show that in the application of a humanistic approach to learning activities, the teachers still need to create a meaningful learning process for students and need to show empathy for the students because in this way the students will want to be directed, guided and also grow a sense of pleasure and enthusiasm for active learning (Stefaroi, 2012). The basic principle of humanistic learning is meaningfulness and from this principle knowledge is then developed to humanize the humans. Humanistic education views humans as free subjects 
in determining the direction of their lives and fully responsible for their own lives. In humanistic learning, an atmosphere of understanding, a loving heart is fostered because the basic principle of humanism is meaningfulness, meaning that meaningfulness results from intense relationships (Gasong \& Toding, 2020).

Furthermore, the result of the data analysis of students' learning motivation variable is described in table 2 .

Table 2. Frequency of Students' Learning Motivation

\begin{tabular}{|c|c|c|}
\hline Indicator & $\begin{array}{c}\text { Frequency } \\
\text { (n) }\end{array}$ & $\begin{array}{c}\text { Percentage } \\
(\%)\end{array}$ \\
\hline \multicolumn{3}{|c|}{ 1. Diligent in facing tasks } \\
\hline Never & 0 & 0.0 \\
\hline Sometimes & 2 & 5.6 \\
\hline Often & 22 & 61.1 \\
\hline Always & 12 & 33.3 \\
\hline \multicolumn{3}{|c|}{ 2. Resilient in the face of adversity } \\
\hline Never & 0 & 0.0 \\
\hline Sometimes & 1 & 2.8 \\
\hline Often & 15 & 41.7 \\
\hline Always & 20 & 55.6 \\
\hline \multicolumn{3}{|c|}{ 3. Showing interest } \\
\hline Never & 0 & 0.0 \\
\hline Sometimes & 3 & 8.3 \\
\hline Often & 16 & 44.4 \\
\hline Always & 17 & 47.2 \\
\hline \multicolumn{3}{|c|}{ 4. Prefer to work independently } \\
\hline Never & 0 & 0.0 \\
\hline Sometimes & 0 & 0.0 \\
\hline Often & 19 & 52.8 \\
\hline Always & 17 & 47.2 \\
\hline \multicolumn{3}{|c|}{ 5. Getting bored of routine tasks } \\
\hline Never & 3 & 8.3 \\
\hline Sometimes & 15 & 41.7 \\
\hline Often & 13 & 36.1 \\
\hline Always & 5 & 13.9 \\
\hline \multicolumn{3}{|c|}{ 6. being able to defend opinions } \\
\hline Never & 0 & 0.0 \\
\hline Sometimes & 14 & 38.9 \\
\hline Often & 19 & 52.8 \\
\hline Always & 3 & 8.3 \\
\hline \multicolumn{3}{|c|}{ 7. not easy to let go of what is believed } \\
\hline Never & 2 & 5.6 \\
\hline Sometimes & 6 & 16.7 \\
\hline Often & 20 & 55.6 \\
\hline Always & 8 & 22.2 \\
\hline \multicolumn{3}{|c|}{ 8. being eager to find and solve questions } \\
\hline Never & 0 & 0.0 \\
\hline
\end{tabular}




\begin{tabular}{lcc}
\hline Sometimes & 0 & 0.0 \\
\hline Often & 18 & 50.0 \\
\hline Always & 18 & 50.0 \\
\hline
\end{tabular}

The variable of students' learning motivation consists of eight indicators in which each indicator consists of two instruments. Based on the results of data analysis as seen in table 2, it is known that the respondents think that they have learning motivation when the teachers applied a humanistic approach in learning activities, although there are several indicators that still need attention. In the indicator of being diligent in facing tasks, 12 respondents $(33.33 \%)$ stated that they were always diligent in facing the task, 22 respondents $(61.1 \%)$ stated that they were often, 2 respondents $(5.6 \%)$ stated that they were sometimes, and no one stated never. It shows that the students have persistence in doing the teaching assignments given by the teachers. This behavior arises when the teachers applied a humanistic approach to learning activities, for example by first creating close and open communication, showing empathy or caring about the complaints experienced by the students, and they are supportive so that the students' desire to learn grows more.

From the indicator of resilience in facing difficulties, 20 respondents (55.6\%) stated that they were always resilient in facing difficulties, 15 respondents $(41.7 \%)$ stated that they were often, 1 respondent $(2.8 \%)$ stated that that he was sometimes, and no respondent stated never. In the indicator of showing interest, 17 respondents $(47.2 \%)$ stated that they always have an interest in learning, 16 respondents (44.4\%) stated often, 3 respondents $(8.3 \%)$ stated sometimes, and no respondent stated never. The data of these two indicators show that the majority of students are resilient in facing difficulties and they are interested in learning activities when the humanistic approach is applied to the learning process by the teachers. The students are treated as individuals who need to be cared for, guided and supported (supportive). The learning atmosphere is created to be fun without threatening punishment so that they can grow their passion in learning.

Furthermore, the indicator of prefer to work independently shows that 17 respondents (47.2\%) stated that they always prefer to work independently, 19 respondents (52.8\%) stated often, and there is no respondent who stated sometimes or never. The data show that the students generally prefer to work independently when the teachers applied a humanistic approach to learning activities. One aspect that is emphasized in the humanistic approach is that the learning activities must be able to foster learning behavior at the initiative of the students themselves (Suzana, Jayanto, \& Farm, 2021).

There are two indicators of learning motivation that need to get attention by the teachers when applying a humanistic approach in learning activities. The first indicator is getting bored quickly on routine tasks, in which 5 respondents $(13.9 \%)$ stated that they always get bored quickly on routine tasks, 13 respondents (36.1\%) stated often, 15 respondents $(41.7 \%) \%$ ) stated sometimes, and 3 respondents (8.3\%) stated never. The data show that the number of respondents who stated sometimes is higher than who stated always and often. The students who have learning motivation will get bored quickly 
if they are given routine tasks (Sardiman, 2011). It means that the teachers still need to optimize the application of a humanistic approach in learning activities, for example by giving more challenging assignments or stimulating the students to be interested in solving new problems so that the learning process experienced by the students can change their habits. One of the concepts of learning with a humanistic approach is learning for change.

The other indicator that needs more attention from teachers is the indicator of being able to defend opinions, in which 3 respondents (8.3\%) stated that they were always able to defend their opinions, 19 respondents (52.8\%) stated often, 14 respondents $(38.9 \%)$ stated sometimes and none of the respondents stated never. The data show that the number of students is sometimes able to maintain their opinion which is quite significant compared to the respondents' choices of answers to the other indicators. One of the characteristics of the students who have learning motivation is that they are able to defend their opinion (Sardiman, 2011). It means that this indicator still needs to be emphasized when the teachers apply a humanistic approach in the learning process. The teachers still need to emphasize the achievement of self-actualization, self-understanding (self-concept) and the development of the potential that exists in the students, so that the students have the ability to defend their opinions (Walton, 2018).

Furthermore, on the indicator of not being easy to let go of what is believed, 8 respondents (22.2\%) stated that they always did not easily let go of what they believed, 20 respondents (55.6\%) stated often, 6 respondents (16.7\%) stated sometimes and 2 respondents $(5.6 \%)$ stated never. The data show that there are some students who sometimes do not even want to maintain what they believe to the maximum, which means that the teachers still need to instill students' self-confidence by emphasizing the development of their potential. On the indicator of being eager to find and solve problems and questions, 18 respondents (50\%) stated that they were always eager to find and solve questions, 18 respondents (50\%) stated often, and there were no respondents who stated sometimes and never. The data show that the students like to find and solve problems when the teachers apply a humanistic approach in learning activities. However, the teachers still need to optimize the implementation of a humanistic approach in learning activities so that the visible learning motivation actually grows in each student so that they learn on their own initiative.

Based on the results of data analysis in table 1 and table 2, it is known that the mean score of the $\mathrm{X}$ variable (humanistic approach) is 3.556 and the mean score of the $\mathrm{Y}$ variable (students' learning motivation) is 3.1725 with a study sample of 36 people. To see the relationship between the humanistic approach by teachers and student motivation, it can be seen in the following figure.

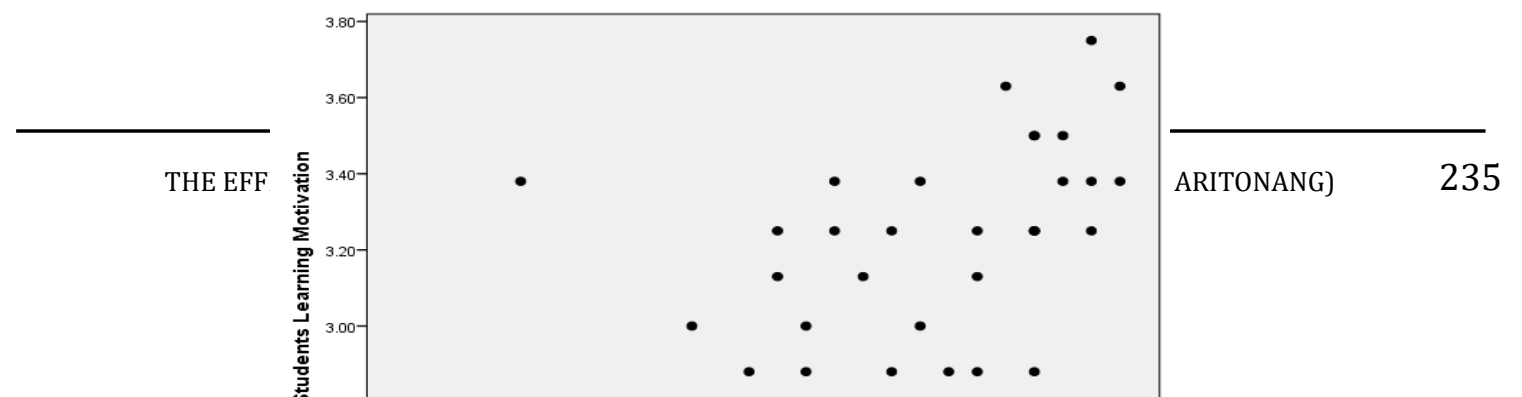


Figure 2. Correlation between Humanistic Approach and Students' Learning Motivation

From figure 2, it is known that the correlation between the humanistic approach and students' learning motivation forms a pattern that increases from left to bottom to top right.

The next step of analysis is to perform regression analysis to find the regression equation. Based on the results of the regression analysis, the regression equation is $\mathrm{Y}=2.5$ $+0.21 \mathrm{X}+\mathrm{e}$. In the regression equation, it is known that the value of $\mathrm{X}$ has a positive value. This shows that humanistic approach that is applied by the teachers can increase students' learning motivation.

Hypothesis testing was carried out using the t-test assisted by the SPSS version 23 application. Based on the analysis, it is known that the significance value of the humanistic approach variable is 0.047 . The significance value of 0.047 is smaller than the value of $0.050(\alpha)$. Therefore, it is indicated that $\mathrm{H} 0$ is rejected and $\mathrm{Ha}$ is accepted. It means that the humanistic approach has a positive and significant effect on students' learning motivation.

\section{CONCLUSION}

As a conclusion, the application of a humanistic approach in the learning process in class XI SMA Negeri 3 Tarutung during the Covid-19 pandemic has a positive and significant effect on students' learning motivation. The students' learning motivation can increase when the teachers apply the humanistic approach better. This is due to the humanistic approach emphasizes several principles, namely learning activities to foster a passion or desire to learn, the principles of meaningful learning, learning without threats, learning on the students' own initiative, learning for change, showing understanding, openness, empathy, and fostering supportive and positive behavior. By applying the principles of a humanistic approach in the learning process will foster motivation to learn within the students themselves.

\section{REFERENCES}

Arbayah. (2013). Model Pembelajaran Humanistik. Dinamika Ilmu, 13(2), 220. 
https://journal.iain-samarinda.ac.id/index.php/dinamika_ilmu/article/view/26.

Farikah, F. (2019). Humanistic Model in teaching Writing: One Step to Develop the Students' Motivation. KnE Social Sciences, 2019, 216-225. https://doi.org/10.18502/kss.v3i17.4643.

Firdaus, F. A., \& Mariyat, A. (2017). Humanistic Approach in Education According to Paulo Freire. At-Ta'dib, 12(2), 25. https://doi.org/10.21111/at-tadib.v12i2.1264.

Gasong, D., \& Toding, A. (2020). Effectiveness of Humanistic Learning Models on Intra and Interpersonal Intelligence. Utopia y Praxis Latinoamericana, 25(Extra 6), 491-500. https://doi.org/10.5281/zenodo.3987667.

Haryanto, \& Irene Astuti Dwiningrum, S. (2020). Humanistic Approaches in Education System of the Industrial Revolution 4.0. Journal Of Archaralogy Of Egypt/Egyptogy, 17(3), 258-274. https://doi.org/10.48080/jae.v17i3.83.

Hasan, M. (2020). Perubahan Paradigma Pendidikan dan Ekonomi di Masa Pandemi Covid19: Peluang, Tantangan dan Strategi.

Munifah, M. P., \& Dodi, L. (2020). Rekonsepsi Pendidikan Karakter Era Kontemporer: Konstruk Epistemologis Penguatan Pendidikan Karakter (PPK) di Indonesia Melalui Evaluasi Model CIPP. Bandung: CV Cendekia Press.

PourAli, P. N., SeifNaraghi, M., \& Naderi, E. (2017). Humanistic Education and Students' Educational Motivation in Tehran Primary Schools. International Journal of Mental Health and Addiction, 15(2), 312-322. https://doi.org/10.1007/s11469-0169703-1.

Rahmat, P. S. (2018). Psikologi Pendidikan. Jakarta: Bumi Aksara.

Rahmi, S. (2021). Komunikasi Interpersonal dan Hubungannya dalam Konseling. Banda Aceh: Syiah Kuala University Press.

Sardiman, A. M. (2011). Interaksi \& Motivasi Belajar Mengajar. Jakarta: Raja Grafindo Persada.

Stefaroi, P. (2012). The humanistic Approach in Psychology \& Psychotherapy, Sociology \& Social Work, Pedagogy \& Education, Management and Art: Personal Development and Community Development. North Charleston, SC: CreateSpace.

Supatminingsih, T., Hasan, M., \& Sudirman. (2020). Belajar dan Pembelajaran. Bandung: Media Sains Indonesia.

Suyanto \& Asep, J. (2013). Menjadi Guru Profesional: Strategi Meningkatkan Kualifikasi dan Kualitas Guru di Era Global. In Esensi. Jakarta.

Suzana, Y., Jayanto, I., \& Farm, S. (2021). Teori Belajar \& Pembelajaran. Literasi Nusantara.

Walton, J. D. (2018). "Your Fears are Appreciated Here": Exploring a Humanistic Approach to Public Speaking Instruction. Administrative Issues Journal: Education, Practice, and Research, 8(1), 28-47. https://doi.org/10.5929/2018.8.1.1. 